\title{
How will Education 4.0 influence learning in higher education?
}

\author{
Alan R. Williams \\ University of Derby, UK \\ Richard Windle \\ University of Nottingham, UK \\ Heather Wharrad \\ University of Nottingham, UK
}

\begin{abstract}
Higher education at the start of the Fourth Industrial Revolution (Schwab, 2015) is undergoing unprecedented change because of the opportunities revealed for using digital technology, referred to as Education 4.0 (Feldman, 2018). Although societies throughout time have undergone seismic change, it is the speed and magnitude of Education 4.0 that is challenging higher education to respond. Changes include access to knowledge, ways that knowledge is shared, and the increasing demand by students for their voices to be heard and to be integral to the design of their learning. However, the opportunities revealed for using digital technology must be carefully managed; it is essential academics and higher education institutions investigate the design of learning objects and ensure an authentic student voice is integral to those resources in the Education 4.0 landscape.
\end{abstract}

Key words: Education 4.0; student voice; higher education; learning objects; Fourth Industrial Revolution 


\section{Learning in the Education 4.0 world}

\section{Education}

Education is central to human existence and has been a part of life since the Greek philosophers and before them (Harasim, 2017). Throughout the ages, education has provided guidance and direction for society, with formal schooling systems in Ancient Greece preparing young men for military service (Matheson, 2015). Many centuries later the First Industrial Revolution provided the impetus for a compulsory education system in the United Kingdom to prepare the population for work in factories. The Second Industrial Revolution around the turn of the $19^{\text {th }}$ century was based on harnessing electrical power, and the Third in the 1950s-60s built on scientific progress from the Second World War, with the 1944 Education Act establishing the grammar, secondary modern and technical schools familiar today (Brock, 2015). Change in compulsory education continues, and Smith (2014, p.16) suggests that the 'spread of ICT is arguably one of the greatest changes that compulsory education has witnessed in the last twenty years'. Schwab (2015) proposes that we are now in the Fourth Industrial Revolution (see Figure $1^{1}$ ), in which technology and the Internet, lifelong learning, and virtual assistants - referred to as Education 4.0 - provide opportunities for higher education to respond to social and political demands (Feldman, 2018).

Figure 1. Industrial Revolutions.

\section{Industrial Revolutions}

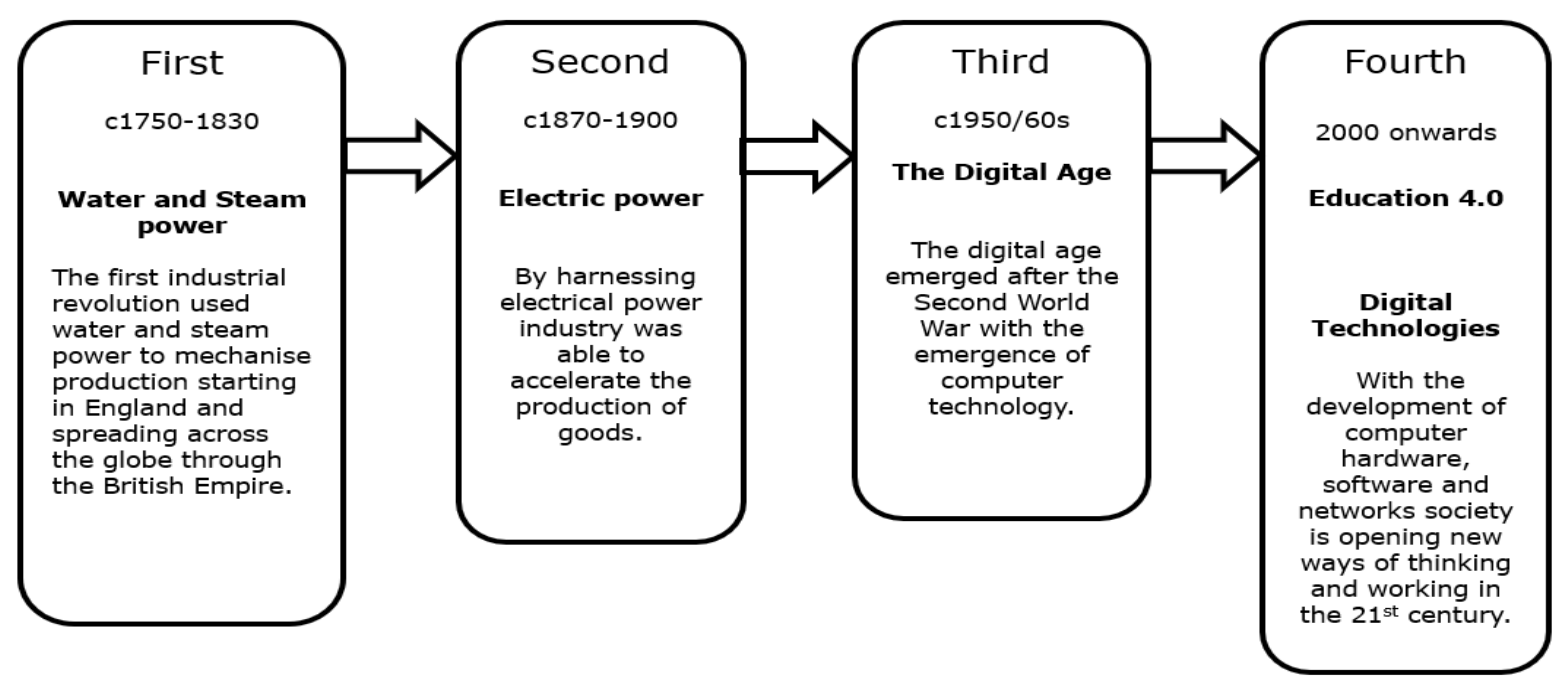

\footnotetext{
1 Figure 1 represents the four industrial revolutions described by Schwab (2015), with an indication of when they occurred and their impact on society.
} 
Compulsory education has had to rapidly adapt to an increasingly technological world over a very compressed time period, compared to education over the millennia. The use of information and communication technology is seen as a part of everyday life (Clarke, 2011). and higher education also has to rapidly comprehend Education 4.0, adopting artificial intelligence such as chatbots and redesigning the campus learning environment (Jisc, 2019; THE, no date). Tierney (2016) considers the role universities play in the $21^{\text {st }}$ century to be based on Cardinal Newman's view that a liberal education was of more benefit than training individuals for specific disciplines. However, in more recent times, some universities have focussed on fostering individuals with the necessary knowledge, skill and abilities to enter a specific profession such as nursing or allied health professions, public service, and surveying because of societal demands, perhaps just as in Ancient Greece.

The generations since World War II have been categorised as Baby Boomers (born 1946), Generation X (1965), followed by Generation Y/Millennials (1977), and those born from 1995 are referred to as Generation Z/Gen Z/ post-Millennials/the iGeneration (Schenarts, 2020). It is Generation $Z$ who have no experience of the world before the web, and who have experienced compulsory education primarily in an online environment; although their teachers educated in an offline world are delivering education in an online world. Although there is no definitive view that categorises individuals as belonging to a specific generation, Strauss and Howe's (1997) discourse on generations and historical events (admittedly with an American focus), provides a starting point to understand the student in higher education today. 
Table 1. Summary of generations

\begin{tabular}{|l|c|c|}
\hline Generation & $\begin{array}{c}\text { Year range born }{ }^{2} \\
\text { (approximate) }\end{array}$ & $\begin{array}{c}\text { Age at the year } \\
\mathbf{2 0 0 0}\end{array}$ \\
\hline Baby Boomer & $1946-1964$ & 36 to 54 \\
\hline Generation X & $1965-1976$ & 24 to 35 \\
\hline Millennials/Gen Y & $1977-1995$ & 5 to 23 \\
\hline $\begin{array}{l}\text { Generation Z/Gen Z/post- } \\
\text { Millennials/the iGeneration/iGen }\end{array}$ & 1995 onwards & 5 \\
\hline
\end{tabular}

Categorising learners by age range alone creates stereotypes that may not truly represent students currently in higher education. Holmes (2011) challenged this simplistic chronological continuum when he analysed young people's use of technology. His analysis of their online activities revealed three types of UK user: one group that embraces the information superhighway for educational and recreational purposes, a second group engaging primarily in recreational activities, and the third group exhibiting a distinct lack of interest in online activity and using technology for homework and little else. COVID-19 (WHO, 2020) has forced compulsory and higher education to embrace many forms of technology in order to deliver education during the pandemic and beyond, and has brought into sharp focus why attention to the design of learning resources is essential.

A binary division categorising students accessing higher education as digital natives or digital immigrants (Prensky, 2001) may be too simplistic, as Sharpe et al. (2005) identify in their report for JISC, and an editorial by Rachel Leaver suggests that natives might be 'more comfortable with the technology but not necessarily having the skills to use it' (Leaver, 2012, p.97). It may be that natives know how to use technology but may not fully appreciate how Education 4.0 tools can enhance their learning and opportunities for education.

Because of the changes in society as a result of Education 4.0 and the learner in the $21^{\text {st }}$ century, it is incumbent on academics and institutions to work with students to design

\footnotetext{
2 The age range ascribed to each generation is an approximation based on literature from Gordon (2010), Hopkins et al. (2018), Oblinger (2003) and Schenarts (2020).
} 
learning that meets all stakeholders' needs, whether that is communication through social media apps, commerce, or co-ordinating their professional and personal lives. Advance HE (2011) highlight the important role technology plays in higher education, recognising the use of 'appropriate learning technologies' in the UK Professional Standards Framework. Digital technology is a dominant force for change and is transforming society over a much shorter time than in previous industrial revolutions (Kahng, 2012; Rodriguez et al., 2015). However, this rapid progress has not allowed time for pedagogical practice to adapt in the way other industries have had to. Education must investigate, understand and adapt to this new environment if learners are to gain the most from these changes in society. It is incumbent on academics and higher education to exploit the opportunities revealed by Education 4.0; those individuals and organisations who do not will be left behind.

\section{The learning environment}

With over half of the world's population online (Kemp, 2018), much of the developed and developing world is dependent on a technological eco-system (Sein-Echaluce et al., 2019) that has rapidly spread since the start of the $21^{\text {st }}$ century. Digital technologies such as hardware (computers, laptops, and 'smart' phones), software and, increasingly, applications (apps) and networks accessed through mobile or wi-fi technologies, are part of everyday life and influence how we engage with individuals and organisations in our professional and personal life. Weiser (1991) discussed the potential of 'ubiquitous computing', by means of which technology is seamlessly integrated into the environment, and the all-pervasive nature of technology is evident in the world now. Without the preceding industrialisation of society, the Fourth Industrial Revolution and Education 4.0 would not be possible; however, it is the ever-increasing pace of change in the $21^{\text {st }}$ century that is different, requiring education to adapt and exploit technology in order to benefit learners.

Education 4.0 has influenced and revealed opportunities to enhance learning in higher education. Education must embrace the opportunities revealed whilst avoiding Gartner's Hype Cycle (Gartner, 2017), which indicates how the actual usefulness of a specific technology can be over played before longer term gains are identified and established. Nevertheless, the changes in society as a consequence of this technological revolution 
have meant the integration of digital technology in education is an expectation for the majority of learners within higher education (Brown, 2015) and in particular for Generation $Z$, who have matured alongside the technology. Expectation drives demand, but if not carefully planned can also lead to poorly designed or delivered educational resources.

\section{Learning design and learning objects}

The tools used in Education 4.0 are primarily digital and, because of their availability, are omnipresent in society. Views regarding the role of technology in learning have changed over time David Wiley described learning objects as 'any digital resource that can be used to support learning' (Wiley, 2000, p.7) moving the discussion from the technical to the educational sphere. He maintained that a learning object by default will be reusable and digital as a result of technology. More recently, Salmon (2013) describes how her 'Carpe Diem' model of learning design, whereby teams enact design ideas on the day, has evolved and spread since 2001; while Dalziel and Dalziel (2012) highlighted the necessity of moving from a technical to a pedagogical approach in learning design in order to enhance education.

Criticism persisted as to what actually defined a learning object (Friesen, 2003) and Metros (2005, p.12) suggested that a learning object 'must include or link to 1) a learning objective, 2) practice activity, and 3) an assessment', although this definition focusses more on institutional requirements than a student-centred approach. Oliver (2007) described an education ecosystem in which learning objects are an essential building block of a university's overarching digital education structure. Jisc (2014) define a learning object as 'an aggregation of one or more digital assets which represents an educationally meaningful stand-alone unit', although only by designing and developing pedagogically useful resources will Education 4.0 provide benefits to all.

Peter Goodyear highlights the need for learning design to assume a greater role in higher education whatever teaching and learning methods are used (Goodyear, 2015) and goes on to explain how 'traditional teaching' in higher education is not fit for purpose because students use the technology they have to hand (laptops, tablets and smart phones) to access learning within and outside traditionally accepted structures. Most importantly 'teaching approaches that may have been the norm 20 or even 10 years ago no longer 
look affordable or appealing' (Goodyear, 2015, p.37), supporting an approach that makes the student central to the design of their learning resources.

\section{Students}

Formal education theories have been developed since the late $19^{\text {th }}$ century with three distinct, although to some degree overlapping, schools of thought referred to as behaviourism, cognitivism and constructivism (Ertmer and Newby, 1993; Woollard, 2011; Harasim, 2017). Disciplines develop and adapt their own brand of educational theory, but, as we are far from understanding how the human brain functions, no one theory can be definitively accepted (Dennick, 2015). However, the democratisation of access to knowledge is also influenced by more active student engagement in learning, reflecting a social constructivist approach to learning and the importance of learning design as identified by Conole (2014) and Laurillard (2002; 2012) among others.

An increase in the number of students entering higher education has been noted in England and in 36 countries (HEFCE, 2015; The Economist, 2018; OECD, 2019) with indicators based on widening participation also demonstrating this trend (Department for Education, 2019). There are a greater number of students entering higher education than two or three decades ago (Department of Business, Innovation and Skills, 2011; 2015; Cable, 2012; McGettigan, 2013) when the use of technology in society was in its infancy meaning educational practice must evolve to take account of changes possible in Education 4.0.

In 2013/2014 there were 1.7 million undergraduate students in higher education in England alone (Higher Education Statistics Authority, no date), and Lord Browne reported that $45 \%$ of 18-30-year-olds in England entered higher education in 2010, an increase from $39 \%$ ten years previously (Browne, 2010). In addition to promoting access to, and participation in, higher education, focus is now turning to graduate success and the employability agenda, with Universities UK (2019) identifying cases where universities, not-for-profit organisations and commercial organisations are addressing this third phase of the widening participation agenda. 
Nearly a decade ago, in the 'Higher Education: Students at the Heart of the System' report (Department of Business, Innovation and Skills, 2011), examples of student engagement cited are student evaluation of teaching and a case report from a university in the Midlands suggesting there is work to do before the student contribution is central to and embedded in the learning design process. Furthermore, with access agreements and a widening participation agenda designed to open universities to underrepresented groups in society (McGettigan, 2013; Matheson and Woodward, 2015), the university student population is more diverse, and educators must consider how learning objects can be designed to meet all students' needs.

More importantly, Generation Z students embarking on higher education study in the first decades of the $21^{\text {st }}$ century have grown up with digital technologies (Hutchinson et al., 2012; Lippencott, 2012; Chung and Fitzsimons, 2013) and will be critical of poorly designed resources. It is important to investigate how this technology can be utilised to achieve more effective learning environments. Grainne Conole suggests that technology is 'central to how they organise and orientate their learning' (Conole, 2008, p.138), and educational practice must accommodate how students learn in order to enable them to reach their full potential. A report for DEMOS that investigated a child's learning in the digital age identified the dominant role technology played in their life and a proportion of these individuals have or are about to enter post-compulsory education (Green and Hanlon, 2007).

\section{Student voice}

With higher education now part of a market economy, Jones-Devitt and LeBihan (2018) suggest that the term 'student voice' can have different interpretations, one being feedback from students on universities and academics, as seen in the United Kingdom in the National Student Survey (NSS, no date). However, the involvement of students in the design of their learning represents a deeper student voice and true partnership because it 1) values their contribution 2) reflects a social constructivist approach to education and 3) is congruent with national policy in the United Kingdom that places the student at the centre of their education. 
Campbell et al. (2009) promote the importance of respecting the student contribution and embedding it in learning and curriculum design, with descriptive evidence of the advantages and challenges ahead. Campbell et al. (2009) report how students can be integral to the design of curricula in law and science (Brooman et al., 2015; Woolmer et al., 2016), although the challenges to enabling a sufficiently loud student voice include 1) ensuring the physical learning environment facilitates students' centrality to their learning and 2) the active engagement of academics, administrators and institutions. Healey et al. (2014) suggest that 'engaging students and staff effectively as partners in learning and teaching is arguably one of the most important issues facing higher education in the $21^{\text {st }}$ century' and provide examples of true student voice in case studies. Another way of achieving true student voice is for learners and academics to undertake pedagogical research projects investigating the design of learning objects fit for Education 4.0, with the dissemination of results providing tangible evidence of achievement for all involved.

\section{Conclusion}

At the dawn of the Fourth Industrial Revolution that brought about Education 4.0, Baby Boomers, Generation $X$ and Generation $Y$ experienced the same changes in technology albeit at different stages of their lives - as Generation Z, who know little else.

Consequently, Generation Z students undertaking higher education in the first decades of the $21^{\text {st }}$ century expect the use of technology in education, and because the previous generations were in their early to mid-adulthood at the dawn of this technological age, they also expect this also to be the norm (Rosen and Nelson, 2008). After all, as Norm Friesen points out, writing and texts have existed for 4,500 years or '150 generational cohorts' (Friesen, 2017, p.151), and we are at the beginning of a new era in education and adapting to how we use these established resources.

Essentially students should not be considered a homogenous group who are au fait with technology; they require support to navigate their learning journey. However, they can make a significant contribution when involved from the start in the design and development of learning objects. Academics must investigate how learning objects are designed and what pedagogical features of a design appear most conducive to the acquisition of knowledge if higher education is to embrace the opportunities of Education 4.0. 


\section{References}

Advance HE (2011) The UK Professional Standards Framework for teaching and supporting learning in higher education 2011. Available at: https://www.advancehe.ac.uk/guidance/teaching-and-learning/ukpsf (Accessed: 30 April 2020).

Brock, C. (2015) 'Social and spatial disparity in the history of school provision in England from the 1750 s to the 1950s', in Matheson, D. (ed.) An Introduction to the Study of Education. Oxford: Routledge.

Brooman, S., Darwent, S. and Pimor, A. (2015) 'The student voice in higher education curriculum design: is there value in listening?' Innovations in Education and Teaching International, 52(6), pp.663-674.

Brown, M. (2015) 'Six trajectories for digital technology in higher education', EDUCAUSE Review, 43(1, pp.16-28.

Browne, J. (2010) Independent Review of Higher Education Funding \& Student Finance. Available at:

https://www.gov.uk/government/uploads/system/uploads/attachment data/file/4225 65/bis-10-1208-securing-sustainable-higher-education-browne-report.pdf (Accessed: 23 January 2020).

Cable, V. (2012) Supporting social mobility and lifelong learning. Available at: https://www.gov.uk/government/speeches/supporting-social-mobility-and-lifelonglearning (Accessed: 23 January 2020).

Campbell, F., Eland, J., Rumpus, A. and Shacklock, R. (2009) Hearing the student voice. Involving students in curriculum design and delivery. Final Report. Available at: http://www.sparqs.ac.uk/ch/E3\%20Hearing\%20the\%20student\%20voice\%20involvi ng\%20students\%20in\%20curriculum\%20design\%20and\%20development.pdf (Accessed: 23 January 2020). 
Chung, S.M. and Fitzsimons, V. (2013) 'Knowing Generation Y: a new generation of nurses in practice'. British Journal of Nursing. 22(20), pp.1173-1179.

Clarke, A. (2011) How to use technology effectively in post-compulsory education. London: Routledge.

Conole, G. (2008) 'Listening to the learner voice: The ever changing landscape of technology of technology use for language students', ReCALL, 20(2), pp.124-140.

Conole, G. (2014) 'The 7Cs of Learning Design - a new approach to rethinking design practice', in Bayne, S., Jones, C., De Laat, M., Ryberg, T, and Sinclair C. (eds.) Proceedings of the 9th International Conference on Networked Learning. University of Edinburgh, Edinburgh 7-9 April.

Dalziel, J. and Dalziel, B. (2012) 'Adoption of learning designs in teacher training and medical education: Templates versus embedded content', Teaching English with Technology, Special Issue on LAMS and Learning Design, 12(2), pp.62-73.

Dennick, R. (2015) 'Theories of learning: constructive experience', in Matheson, D. (ed.) An Introduction to the Study of Education. Oxford: Routledge.

Department for Education (2019) Widening Participation in Higher Education, England, 2017/18 age cohort - Official Statistics. Available at:

https://assets.publishing.service.gov.uk/government/uploads/system/uploads/attach ment data/file/852633/WP2019-MainText.pdf (Accessed: 23 April 2020).

Department of Business, Innovation and Skills (2011) Higher Education: Students at the heart of the system. $\mathrm{Cm}$ 8122. Available at:

https://assets.publishing.service.gov.uk/government/uploads/system/uploads/attach ment data/file/31384/11-944-higher-education-students-at-heart-of-system.pdf (Accessed: 19 May 2020). 
Department of Business, Innovation and Skills (2015) Teaching at the heart of the system. Available at: https://www.gov.uk/government/speeches/teaching-at-the-heart-of-thesystem (Accessed: 23 January 2020).

The Economist (2018) 'Time to end the academic arms race'. 3 February, p. 16. Available at: https://www.economist.com/leaders/2018/02/03/time-to-end-the-academic-armsrace (Accessed: 23 January 2020).

Ertmer, P. and Newby, R. (1993) 'Behaviourism, cognitivism, constructivism: comparing critical features from an instructional design perspective', Performance Improvement Quarterly. 6(4), pp.50-72.

Feldman, P. (2018) The potential of Education 4.0 is huge - the UK must take the lead, now. Available at: https://www.jisc.ac.uk/blog/the-potential-of-education-4-is-hugethe-uk-must-take-the-lead-now-12-sep-2018\# (Accessed: 24 April 2020).

Friesen, N. (2003) Three Objections to Learning Objects and E-learning Standards. Available at: https://www.normfriesen.info/papers/objections.html (Accessed: 27 April 2020).

Gartner (2017) Gartner Hype Cycle. Available at: https://www.gartner.com/technology/research/methodologies/hype-cycle.jsp (Accessed: 23 January 2020).

Goodyear, P. (2015) 'Teaching as design', HERDSA Review of Higher Education, 2, pp.27-50. Available at http://www.herdsa.org.au/herdsa-review-higher-educationvol-2/27-50 (Accessed: 23 January 2020).

Gordon, S. (2010) 'Once you get them, how do you keep them? Millennial librarians at work', New Library World. 111(9/10), pp.391-398. Available at: https://doi.org/10.1108/03074801011089314 (Accessed: 23 January 2020).

Green, H. and Hanlon. C, (2007) Young people are spending their time in a space which adults find difficult to supervise or understand. Available at: 
http://dera.ioe.ac.uk/23215/1/Their\%20space\%20-\%20web.pdf (Accessed: 23 January 2020).

Harasim, L. (2017) Learning theory and online technologies. $2^{\text {nd }}$ edn. Abingdon: Routledge.

Healey, M., Flint, A. and Harrison, K. (2014) Engagement through partnership: students as partners in learning and teaching in higher education. Higher Education Academy. Available at www.heacademy.ac.uk/students-as-partners (Accessed: 29 April 2020).

Higher Education Funding Council for England [HEFCE] (2015). Young Participation in Higher Education: A-Levels and Similar Qualifications. Issues paper 2015/03. Available at: https://dera.ioe.ac.uk/22198/1/HEFE2015 03.pdf (Accessed: 19 May 2020).

Higher Education Statistics Authority (no date) Free Online Statistics - Students \& qualifiers. Available at: https://www.hesa.ac.uk/stats (Accessed: 23 January 2020).

Holmes, J. (2011) 'Cyberkids or divided generations? Characterising young people's internet use in the UK with generic continuum or typological models', New Media and Society, 13(7), pp.1104-1122.

Hopkins, L., Hampton, B., Abbott, J., Buery-Joyner, S., Craig, L., Dalrymple, J., Forstein. D., Graziano, S., McKenzie, M., Pradham, A., Wolf, A. and Page-Ramsey, S. (2018) 'To the point: medical education, technology, and the millennial learner', American Journal of Obstetrics and Gynaecology, 218(2), pp.188-192.

Hutchinson, D., Brown, J. and Longworth, K. (2012) 'Attracting and maintaining the $Y$ Generation in nursing: a literature review', Journal of Nursing Management, 20, pp.444-450.

Jisc (2014) Open educational resources (OERs) guide. Available at:

https://www.jisc.ac.uk/full-guide/open-educational-resources (Accessed 27 April 2020). 
Jisc (2019) Members stories: moving towards Education 4.0. Available at:

https://www.jisc.ac.uk/blog/member-stories-towards-higher-education-40-15-jan2019\# (Accessed 29 April 2020).

Jones-Devitt, S. and LeBihan, J. (2018) Use and abuse of the student voice. Available at: https://www.advance-he.ac.uk/knowledge-hub/use-and-abuse-student-voice (Accessed 29 April 2020).

Kahng, A. (2012) 'The road ahead. Predicting the future of information technology and society', IEEE Design and Test of Computers, November/December, pp.101-102.

Kemp, S. (2018) Digital in 2018: world's internet use passes the 4 billion mark. Available at https://wearesocial.com/blog/2018/01/global-digital-report-2018 (Accessed 24 April 2020).

Laurillard, D. (2002) Rethinking university teaching: a conversational framework for the effective use of learning technologies. $2^{\text {nd }}$ edn. London: RoutledgeFalmer.

Laurillard, D. (2012) Teaching as a design science: building pedagogical patterns for learning and technology. London: RoutledgeFalmer.

Leaver, R. (2012) 'Blending with the digital natives', International Journal of Urological Nursing, 6(3), pp.97-99.

Lippencott, J. (2012) 'Information commons: Meeting millennials' needs', Journal of Library Administration, 52(6-7), pp.538-548.

Matheson, C. and Woodward, D. (2015) 'Post-compulsory education (further and higher education)', in Matheson, D. (ed.) An Introduction to the Study of Education. $4^{\text {th }}$ edn. London: Routledge.

Matheson, D. (2015) 'What is education?', in Matheson, D. (ed.) An Introduction to the Study of Education. $4^{\text {th }}$ edn. London: Routledge. 
McGettigan, A. (2013) The Great University Gamble; money, markets and the future of higher education. London: Pluto Press.

Metros, S.E. (2005) 'Learning objects: a rose by any other name', EDUCAUSE Review, 40 (4), pp.12-13.

NSS (no date) About the NSS. Available at: https://www.thestudentsurvey.com/about.php (Accessed: 29 April 2020).

Oblinger, D. (2003) Boomers, Gen-Xers and Millennials: understanding the new students. Available at: https://er.educause.edu/articles/2003/1/boomers-genxers-andmillennials-understanding-the-new-students (Accessed: 23 January 2020).

OECD (2019) Education at a Glance 2019: OECD Indicators. OECD Publishing: Paris. Available at: https://doi.org/10.1787/f8d7880d-en (Accessed: 21 May 2020).

Oliver, R. (2007) 'Reusing and sharing learning designs in higher education', in Crisp, G. and Hicks, M. (eds) Enhancing Higher Education, Theory and Scholarship: Proceedings of the 30 $30^{\text {th }}$ HERDSA Annual Conference, Adelaide, 8-11 July, pp. X429.

Prensky, M. (2001) 'Digital natives, digital immigrants', On the horizon, 9(5), pp.1-6.

Rodriguez, D., Busco, C. and Flores, R. (2018) 'Information technology within society's evolution', Technology in Society, 40, pp.64-72.

Rosen, D. and Nelson, C. (2008) 'Web 2.0: A new generation of learners and education', Computers in the Schools, 25(3-4), pp.211-225.

Salmon, G. (2013) E-tivities: the key to active online learning. $2^{\text {nd }}$ edn. London: Routledge.

Schenarts, P.J. (2020) 'Now arriving: Surgical trainees from Generation Z', Journal of Surgical Education, 77(2), pp.246-253. 
Schwab, K. (2015) 'The Fourth Industrial Revolution; What it means and how to respond', Foreign Affairs, 12 December. Available at:

https://www.foreignaffairs.com/articles/2015-12-12/fourth-industrial-revolution (Accessed: 23 January 2020).

Sein-Echaluce, M., Fidalgo-Blanco, A. and Esteban-Escano, J. (2019) 'Technological ecosystems and ontologies for an educational model based on Web 3.0', Universal access in the Information Society, 18, pp.645-658. Available at: https://doi.org/10.1007/s10209-019-00684-9 (Accessed: 21 May 2020).

Sharpe, R., Benfield, G., Lessner, E. and DiCicco, E. (2005) Scoping study for the pedagogy strand of the JISC e-learning programme. Available at:

https://www.researchgate.net/publication/295400695 Scoping study for the peda gogy strand of the Jisc eLearning programme (Accessed: 23 January 2020).

Smith, L. (2014) 'ICT for English in English ITE: An investigation into the ICT component of PCGE English courses', English in Education, 48:1, pp.63-75, Available at: https://doi.org/10.1111/eie.12037 (Accessed: 21 May 2020).

Strauss, W. and Howe, N. (1997) The Fourth Turning: an American Prophecy. New York: Broadway Books.

THE (no date) Preparing for Education 4.0. Available at: https://www.timeshighereducation.com/hub/jisc/p/preparing-education-40 (Accessed: 29 April 2020).

Tierney, W. (2016) 'Portrait of higher education in the twenty-first century: John Henry Newman's 'The idea of a university", International Journal of Leadership in Education, 19, pp.5-16.

Universities UK (2019) Widening opportunity in higher education - the third phase: beyond graduation. Available at: https://www.universitiesuk.ac.uk/policy-andanalysis/reports/Pages/widening-opportunity-third-phase-beyond-graduation.aspx (Accessed 29 April 2020). 
Weiser, M. (1991) 'The computer for the $21^{\text {st }}$ century'. Scientific American. 265(3), pp.6675.

WHO (2020) Coronavirus disease (COVID-19) pandemic. Available at: https://www.who.int/emergencies/diseases/novel-coronavirus-2019 (Accessed 29 April 2020).

Wiley, D. (2000) 'Connecting learning objects to instructional design theory: A definition, a metaphor, and a taxonomy', in Wiley, D. (ed) The Instructional Use of Learning Objects. Available at: http://www.reusability.org/read/\#1 (Accessed: 23 January 2020).

Woollard, J. (2011) Psychology for the classroom: e-learning. Abingdon: Routledge.

Woolmer, C., Sneddon, P., Curry, G., Hill, B., Fehertavi, S., Longbone, C. and Wallace, K. (2016) 'Student staff partnership to create an interdisciplinary science skills course in a research intensive university', International Journal for Academic Development, 21(1), pp.16-27.

\section{Author details}

Alan Williams is Academic Lead for the Nursing and Perioperative Practice programmes at the University of Derby Online Learning. He is a registered nurse with over 20 years' experience in the NHS before moving to higher education as an Assistant Professor at the University of Nottingham in 2006. He completed his doctoral thesis in 2018 investigating the design of learning objects, under the supervision of Dr Windle and Professor Wharrad and now applies his knowledge and experience to support online students across the globe.

Richard Windle is an Associate Professor at the University of Nottingham, Faculty Digital Learning Director and a Principal Fellow of the HEA. Ever since appointment as a Lecturer in Health Sciences in 1999, he has had a passion for exploring how digital learning 
technology can be used to support learner-empowerment and ownership in order to address the learning needs of his students.

Heather Wharrad is a Professor of e-Learning and Health Informatics at the University of Nottingham. She is academic lead for the HELM - Health E-learning and Media group and the research group in Education and Technology for Health in the School and has been principal investigator on many externally funded national and international projects on e-learning pedagogy, evaluation and research in health. 